\title{
İlkokul Öğretmenlerinin Glokal Liderlik Davranışlarını Gösterme Düzeyleri
}

\author{
DOI: 10.26466/opus.585869
}

\begin{abstract}
Sait Akbaşl1* - Şefika Şule Erçetin** - Harun Yüce ${ }^{* * *}$
* Doç. Dr., Hacettepe Üniversitesi, Eğitim Yönetimi Ana Bilim Dalı, Çankaya / Ankara / Türkiye E-Posta: sakbasli@gmail.com

ORCID: 0000-0001-9406-8011

** Prof. Dr., Hacettepe Üniversitesi, Eğitim Yönetimi Ana Bilim Dalı, Çankaya /Ankara / Türkiye E-Posta: sefikasule@gmail.com ORCID: $\underline{0000-0002-7686-4863}$

*** YL. Öğr., Hacettepe Üniversitesi, Eğitim Yönetimi Ana Bilim Dalı, Çankaya / Ankara / Türkiye E-Posta: yuceharri@gmail.com ORCID: 0000-0001-6418-6957
\end{abstract}

$\ddot{O} z$

İçinde bulunduğumuz dünya düzeni tüm iş çevrelerince kapitalist dünya düzeni olarak anılmaktadır. Bahsi geçen bu düzen, 18. yy' da "Sanayi Devrimi" ile birlikte egemen güç hâline gelmiş ve mevcut gücünü hâlen korumaktadır. İlkokul öğretmenlerinin glokal liderlik davranışlarını gösterme düzeylerini ve yine ilkokul öğretmenlerinin glokal liderlik davranışların gösterme düzeylerinin demografik özelliklere (yaş, cinsiyet, kıdem, eğitim seviyesi) göre farklılaşma gösterip göstermediğini belirlemek amacıyla yürütülmüş̧ olan bu çalışma betimsel bir çalışmadır. Bu amaçla, 4 alt boyuttan, her boyutta 7 maddeden ve toplamda 28 maddeden oluşan "Çok Boyutlu Glokal Liderlik Ölçeği" ve çalışma grubunun demografik özelliklerinin saptanması amacıyla "Bilgi Formu" veri toplama aracı olarak kullanılmıştır. Araştırmanın çalışma grubunu Ankara ili Sincan Bölgesi Yenikent İlkokulunda hâlen görev yapan 51 ilkokul öğretmeni oluşturmuştur. Bulgulara göre ilkokul öğretmenlerinin glokal liderlik davranışların gösterme düzeyleri "ara sıra" bulunmuş, alt problemi oluşturan demografik özelliklere göre glokal liderlik davranışlarının farklılaşma durumunun incelenmesi sonucunda ise yaş, cinsiyet kıdem ve eğitim seviyesi değişkenlerinin hiçbirinde anlamlı bir farklılık bulunmamıştır.

Anahtar Kelimeler: Global, lokal, glokal, glokal liderlik, ilkokul öğretmeni 


\title{
Display Levels of Primary School Teachers Glocal Leadership Behaviors
}

\begin{abstract}
The current world order is known as the capitalist world order by all business circles. This order became a dominant power in the 18th century with the 'Industrial Revolution' and still maintains its current power. This is a descriptive study that has been conducted both to analyze the display levels of primary school teachers' glocal leadership behaviors and to determine whether the display levels of primary school teachers' glocal leadership behaviors change according to the demographic factors (age, gender, seniority, educational level) or not. For that purpose, the "Multidimensional Glocal Leadership Scale" which includes 4 sub-dimensions that each of them has 7 different subjects (overall 28 subjects) and "Information Form" to detect the demographic characteristics of the workgroup have been used as data tools. The workgroup of the study has been composed of 51 primary school teachers who work at Yenikent Primary School in Sincan in Ankara. According to the results, it has been found that primary school teachers show glocal leadership behaviors "rarely", and with regard to the demographic factors related to subproblem; the variables that are age, gender, seniority and education level have not made any significant differences as a result of the examination of glocal leadership behavioral differentiation.
\end{abstract}

Keywords: Global, local, glocal, glocal leadership, primary school teacher 


\section{Giriş}

İnsan, sürekli olarak değişen, gelişen sosyo-kültürel bir varlıktır. Sosyokültürel olması, insanın, doğası gereği diğer insanlarla etkileşim hâlinde olmasının bir sonucudur. Bu etkileşim süreci, örgüt adı verilen insan topluluklarının ortaya çıkışına zemin hazırlar. Örgütler, belirli amaçları gerçekleştirmek için oluşturulmuş sosyal sistemlerdir. Sosyal sistemler birey ağırlıklıdır, amaç yönelimlidir ve aynı zamanda çevresine karşı açıktır. Bütün sosyal sistemlerin, göreli olarak durağan olarak nitelendirilebilecek etkinlikleri ve işlevleri bulunmaktadır. Bu çerçevede sosyal sistemin doğası ne olursa olsun sistemde gösterilen davranış eğilimleri düzenli ve rutindir (Hoy ve Miskel, 2010).

Sosyal sistemlerin üyeleri olan insanlar taşıdıkları niteliklere göre grup içerisinde sorumluluk alırlar. Bu görev dağılımı esnasında kimi kişi ya da kişiler ön plana çıkarlar. Lider adı verilen bu kişiler, grup üyeleri üzerinde önemli bir etkiye sahiptir. Liderler, izleyenlerin; inanç ve değerlerini, olayları yorumlama tarzlarını, belirli amaçları başarma konusundaki güdülerini, beceri ve özgüvenlerini, amaçlarını ve karşılıklı güven ve işbirliğini etkilemektedir (Bolden, Gosling, Marturano; ve Dennison, 2003). Liderlikle ilgili kuramlar, örgütlerin ve toplumların sosyal ve politik özelliklerinden ayrı olarak ele alınamaz. Bu bağlamda iyi bir liderden, yaşadığı toplumun sosyal, kültürel değişimlerini iyi analiz ederek ve toplumun bütün dinamiklerini anlamaya çalışarak hareket etmesi beklenmektedir (Kantos, 2011).

Eğitim yönetimi açısından liderlik ayrı bir öneme sahiptir. Ancak eğitim yönetimi denilince akla gelen liderlik türleri çoğunlukla eğitim liderliği ve öğretim liderliği olmuş, bu liderlik türleri ise genellikle yönetici bazında ele alınmıştır. Ne yazık ki işin asıl mutfağındaki öğretmenler, içinde bulundukları sınıf ortamının lideri olarak arka plânda kalmıştır. Oysa öğretmenler, alanyazında özellikleri geçen eğitim liderliği ve öğretim liderliği boyutlarının ikisini de kapsayan bir konumda yer almaktadırlar. Rupisiene ve Skarbalienė (2010) öğretmen liderlerin kişisel standartlarının yüksek, en iyi olmak için istekli, okul ve öğretmenliğe ilişkin güçlü bir vizyona sahip, olumsuzluklara karşı kendini kontrol edebilen ve direnç gösteren, tarafsız, sorunlara çözümler üretebilen, sorumluluklarını bilen, motivasyon ve ilham kaynağı olan kişiler olduklarını belirtmektedirler. 
Alanyazında yeterince yer almayan öğretmen liderliği ile ilgili olarak ilk akla gelen konu, eğitim, öğretim ve liderlik boyutlarında görevleri olan öğretmenlerin liderlik özelliklerinin hangi alt başlıklarda inceleneceğine ilişkindir. Söz konusu konu, liderlik kuramları tarafından farklı açılardan ele alınmaktadır. Bu kuramlar arasında yer alan 'glokal liderlik" liderliği farklı bir bakış açısıyla ele almaktadır.

\section{Glokal Liderlik}

Ülkeler ve kuruluşlar açısından en önemli varlıklar liderlerdir. On dokuzuncu yüzyılın ilk yarısından itibaren alanyazında yer alan liderlik ile ilgili olarak günümüze kadar birçok teori ve görüş ortaya atılmıştır. Liderlik davranışları ve başarılarının izleyicilerin başarısını beraberinde getiriyor oluşu, değişimin hızlı ve rekabetin yüksek olduğu günümüzde liderliği, geçmişten daha önemli bir hale getirmiştir (Dinçman, 2016).

İçinde bulunduğumuz dünya düzeni, tüm iş çevrelerince kapitalist dünya düzeni olarak anılmaktadır. "Sanayi Devrimi" ile birikte egemen güç haline gelen bu düzen, mevcut gücünü hâlen korumakta ve tüm dünyayı kendisine hizmet etmeye zorlamaktadır. Kapitalist dünya düzenine yeterince uyum sağlayamayan ve globalleşemeyen ülkeler ise bu düzende geri kalmış ülkeler olarak kabul edilmektedir. Kapitalizm, üretim-tüketim odaklı bir kavram olarak ülkeleri, sanayilerini tüm dünyaya açmaya mecbur bırakmıştır. Bu durumda ise ülkeler küresel düşünmeye mecbur bırakılmış, bu beceriye sahip olmayan ülkeler ise "geri kalmış ülkeler" olarak adlandırılmıştır. Günümüzde ise küresel düşünmek artık yetmemekte, bu düşünce yapısını yerele uygulamak, bir zorunluluk olarak karşımıza çıkmaktadır. "Glokal" kavramı da adını buradan almaktadır. Bu kavram, "Küreselleşme" ve "yerelleşme"nin bir birleşimi olarak alanyazında kendine yer bulmuştur.

"Glokal" ve "Liderlik" kavramlarının birlikte anılması oldukça yenidir. Bu iki kavramın birleşimi olan "glokal liderlik", ilk olarak 2003 yılında Begley ve Boyd tarafından ortaya konmuştur. Begley ve Boyd'a göre glokal liderlik, aynı zamanda, hem global düşünmeyi hem de yerel düşünmeyi gerektirmektedir (Erçetin, Potas, Açıkalın, Yılmaz, Kısa, Güngör, 2017, s.76). Başka bir ifade ile glokal liderlik, global ölçekteki liderlik becerilerinin, yerel ihtiyaçlara göre şekillendirilmesidir. 
Chappelet'a (2009) göre glokallik, glokal ve yerel boyutların dengelendiği bütüncül bir yaklaşımdır (aktaran; Erçetin vd. , 2017, s.76). Aynı coğrafyada yaşayan insanların inanışsal, geleneksel ve yaşantısal ilişkilerini yerleşik global kültürel güç çizgisinde açılamaya çalışan bir tür terimdir (Kalay, 2016, aktaran; Erçetin vd. , 2017, s.76).

Erçetin, ve diğerlerine (2017) göre glokal liderlik üç bileşenden oluşmaktadır: "global düşünme", "yerel düşünme", "aynı zamanda hem global hem yerel düşünme". Bahsi edilen bu üç boyutun eğitim örgütlerinin içerisine dâhil edilmesinde okul yöneticileriyle birlikte öğretmenlere de önemli görevler düşmektedir. Böylelikle eğitim örgütleri global dünyanın gerçeklerine göre eğitim hizmetlerini sunarken yerel ihtiyaçları da karşılar hale gelecektir.

Glokal liderlik alanyazında çeşitli boyutlarda incelenmiştir. Brooks ve Normore'ye (2010) göre glokal liderlik; (i) politik okuryazarlık, (ii) ekonomik okuryazarlık, (iii) kültürel okuryazarlık, (iv) manevi okuryazarlık, (v) pedagojik okuryazarlık, (vi) bilgi okuryazarlı̆̆ı, (vii) örgütsel okuryazarlık, (viii) ruhsal ve dini okuryazarlık, (ix) içinde bulunulan çağın okuryazarlığ1 gibi boyutlardan oluşmakta iken Erçetin ve Hamedoğlu'na (2007) göre glokal liderlik; (i) vizyon sahibi olma, (ii) global okuryazarlık, (iii) milliyet, (iv) paylaşılan liderlik, (v) etik boyutlarını içermektedir (aktaran; Erçetin vd. , 2017, s. 75). Bu araştırmada ise glokal liderlik, Erçetin, Potas, Açıkalın ve Kısa (2011) tarafından geliştirilen Çok Boyutlu Glokal Liderlik Ölçeği'nde yer alan (i) vizyon sahibi olmak, (ii) sosyal ağların yönetimi, (iii) küresel okur-yazarlık, (iv) yerel okuryazarlık boyutları çerçevesinde ele alınmıştır. Burada, vizyonerlik, sosyal ağların yönetimi, küresel okur yazarlık ve yerel okur yazarlık kavramlarına kısaca değinmek, çalışmanın anlaşılırlığı açısından önemli olacaktır.

\section{Vizyonerlik}

“Vizyon, kelime anlamıyla görüş, görme kuvveti, geleceği kestirebilme gücü ve hayal gücü gibi anlamlara gelmektedir. Vizyon, ülkemizde daha çok politik liderlerin, geleceğe yönelik bakış açıları olarak kullanılmıştır" (Erçetin, 2000). Ancak bu kavramı, eğitimsel uygulamaların içerisine dahil etmek, küreselleşen dünyada olmazsa olmaz bir durum olarak karşımıza çıkmaktadır. 
Eğitim alanında vizyon denilince ilk akla gelen kuşkusuz ki okul müdürleri ve yöneticiler olacaktır. Bir yöneticinin vizyonu, o örgütteki çalışanların vizyonlarını doğrudan etkiler. Ancak burada yine işin öğretmen boyutuna değinmek gerekir. Bir öğretmen, eğitimsel hedefleri gerçekleştirirken kendi dünyasına sıkışıp kalmamalı, tüm dünyada olan biten gelişmeleri, yenilikleri eğitimsel süreçlerin içerisine dahil etmelidir. Bunu da ancak az önce vizyonu tanımlarken sözü edilen "geleceği kestirme kuvveti" ile başarabilir. Öğretmenin, kendi çok boyutluluğundan hareketle öğrencilerini de bu doğrultuda geliştirmesi oldukça önemlidir.

\section{Sosyal Ağlarn Yönetimi}

21. yy, bilgi teknolojilerinin patlama yaptığı bir zaman dilimini içermektedir. Bu zaman dilimi içerisinde insanlar, kendi hayatlarını neredeyse tamamen teknolojik gelişmelerin içerisine dahil etmekte, tüm dünya ile etkileşimini burada gerçekleştirmektedir. Hâl böyle olunca sosyal ağların kullanımı eğitim açısından da oldukça önemli bir duruma evrilmiştir. Öğretmen, sosyal ağların gücünden maksimum düzeyde yararlanabilmeli, eğitimsel amaçların gerçekleştirilmesi doğrultusunda bu gücü etkili kullanıma doğru sürüklemelidir. Bu etkililik ise var olan bilgilerin edinilmesi ve paylaşılması ile meydana gelebilir.

\section{Küresel Okuryazarlik}

“Küreselleşme; gruplar, ülkeler, bölgeler arasında ekonomik, teknolojik, siyasal ve kültürel ilişkilerin artması ile karşılıklı olarak daha fazla etkileşimi; sınır tanımaz gelişmelerle millî sınırların zayıflatılması sonucu küresel toplum ve vatandaşlık bilinci geliştiren süreçler, kabuller ve yaptırımları içeren geniş bir kavramdır"'(Çınar, 2009, s. 14). Küreselleşmenin etkisiyle, toplumsal bir dönüşüm yaşanmakta ve tüm kurum ve kuruluşlar küresel bir yapıya bürünmektedir. Söz konusu durum eğitimsel süreçleri etkisi altına alarak eğitimin küreselleşmesine neden olmuş ve burada küresel okuryazarlık kavramı ortaya çıkmıştır. Öğretmenler küresel okuryazarlık kapsamında, bireysel ve örgütsel düzeyde gerçekleştirilen uygulamaların başka ülkelerdeki bireyleri ve örgütleri etkileyebileceğini kestire- 
bilmeli, karmaşıklığı yönetebilmek için işlerin basit ve uyumlu hâle gelmesini sağlayabilmelidir. Öğretmenlerin bütün bunları yapabilmesi için de dünyada olup bitenleri sorgulayıcı ve araştırıcı bir gözle takip edebilmesi gerekmektedir.

\section{Yerel Okuryazarlik}

Brooks ve Normore'ye (2010) göre herkes, bireysel bir kültüre sahiptir. Bir ülkede eğitimin amaçları belirlenirken o kültürün ögeleri işin içine sadece amaç olarak katılmayıp süreç olarak da dâhil edilir. Bu sebeple içinde bulunulan kültürün değerlerinin, gereksinimlerinin bilincine varmak ve bu bilinç doğrultusunda eğitimsel süreçleri işe koşmak oldukça önemlidir. Bu noktada öğretmene oldukça önemli görevler düşmektedir. Öğretmen, önceden belirlenen eğitimsel amaçları ve süreçleri içselleştirip kendisini bu doğrultuda öğrencilerine adamakla yükümlüdür.

Glokal liderlik, görece yeni bir liderlik konusu olmasına rağmen özellikle yabancı alanyazında oldukça geniş araştırma imkânları sunmaktadır. Yabancı alanyazındaki bu genişliğin yerele uygulanması amacıyla oluşturulan bu makalede "öğretmen", ilk kez glokal liderlik bağlamında ele alınmıştır. Bu durum araştırmanın önemini ortaya koymaktadır.

Yerel alanyazında glokal liderlik konulu araştırmalar incelendiğinde, bu konuda yeterince çalışma ortaya konmadığı görülmektedir. Bu konuda Erçetin ve diğerleri (2017) tarafından, “Özel Enstitülerde Çalışan Yöneticilerin Glokal Liderlik Davranışları" ve Canbolat, Mumcu, Şahan, Öcal, ve Akdoğan (2018) tarafından, “Eğitim Bilimleri Ensitülerinde Glokal Liderliğin Uygulanabilirliği" başlıklı makaleler kaleme alınmıştır. Yabancı alanyazında ise; Brooks ve Normore (2010), "Eğitim Liderliği ve Küreselleşme: Glokal Perspektifte Okuryazarlık” çalışmaları ile glokal liderliği çeşitli boyutlar altında incelemiş, Weber E. (2007), Küreselleşme, "Glokal Gelişme ve Öğretmenin İşi: Bir Araştırma Gündemi” başlıklı makalesi ile Güney Afrika'yı örneklem aldığı bir örnek olay çalışması gerçekleştirmiş, Adifatoni (2016) ise "Glokal Perspektifte Eğitim Liderliği" başlıklı makalesi ile liderlik türlerini incelemiştir.

Bu çalışmada temel amaç, "ilkokul öğretmenlerinin glokal liderlik davranışlarını gösterme düzeylerinin saptanması" dır. Ayrıca, sözü edilen bilgilerden hareketle araştırma kapsamında şu sorulara cevap aranmıştır: 
1. İlkokul öğretmenlerinin glokal liderlik davranışlarını gösterme düzeyleri nedir?

2. İlkokul öğretmenlerinin glokal liderlik davranışlarını gösterme düzeyleri demografik özelliklere (cinsiyet, yaş, kıdem, eğitim seviyesi) göre anlamlı bir farklılık göstermekte midir?

\section{Yöntem}

\section{Araştırmanın Modeli}

İlkokul öğretmenlerinin glokal liderlik davranışlarını gösterme düzeyleri ve bu düzeylerin demografik özelliklere (cinsiyet, yaş, kıdem, eğitim seviyesi) göre farklılaşıp farklılaşmadığının belirlenmesi amacıyla yapılan bu çalışmada betimsel metod kullanılmıştır. Betimsel metod, nicel veriler ile istatistikî olanaklar sağlar. Knupfer ve McLellan'a (1996) göre betimsel metod, durumun kendi doğasında gözlenmesine imkân verir (Erçetin vd., 2017, s. 75).

\section{Evren ve Örneklem}

Araştırma, Ankara Yenikent İlkokulu ilkokul (sınıf) öğretmenleri (51) ile gerçekleştirilmiştir. Çalışmaya katılan öğretmenlerin cinsiyet, yaş, kıdem ve eğitim seviyesine göre dağılımları Tablo 1, Tablo 2, Tablo 3 ve Tablo $4^{\prime}$ te sunulmuştur.

Tablo 1. Çalışmaya Katılan İlkokul Öğretmenlerinin Cinsiyete Göre Dağılımı

\begin{tabular}{llllll}
\hline \multirow{2}{*}{ Geçerli } & & Frekans & Yüzde & Geçerli Yüzde & Birikimli Yüzde \\
\cline { 2 - 6 } & Erkek & 10 & 19,6 & 19,6 & 19,6 \\
\hline & Kadın & 41 & 80,4 & 80,4 & 100,0 \\
\hline
\end{tabular}


Tablo 2. Çalışmaya Katılan İlkokul Öğretmenlerinin Yaşa Göre Dağılımı

\begin{tabular}{llllll}
\hline & & Frekans & Yüzde & Geçerli Yüzde & Birikimli Yüzde \\
\hline \multirow{5}{*}{ Geçerli } & $25-29$ & 11 & 21,6 & 21,6 & 21,6 \\
\cline { 2 - 6 } & $30-34$ & 10 & 19,6 & 19,6 & 41,2 \\
\cline { 2 - 6 } & $35-39$ & 16 & 31,4 & 31,4 & 72,5 \\
\cline { 2 - 6 } & $40-44$ & 6 & 11,8 & 11,8 & 84,3 \\
\cline { 2 - 6 } & $45-49$ & 5 & 9,8 & 9,8 & 94,1 \\
\cline { 2 - 6 } & $50-54$ & 3 & 5,9 & 5,9 & 100,0 \\
\cline { 2 - 6 } & Toplam & 51 & 100,0 & 100,0 & \\
\hline
\end{tabular}

Tablo 3. Çalışmaya Katılan İlkokul Öğretmenlerinin Kıdeme Göre Dağılımı

\begin{tabular}{|c|c|c|c|c|c|}
\hline & & Frekans & Yüzde & Geçerli Yüzde & Birikimli Yüzde \\
\hline \multirow[t]{8}{*}{ Geçerli } & $0-4$ & 6 & 11,8 & 11,8 & 11,8 \\
\hline & $5-9$ & 12 & 23,5 & 23,5 & 35,3 \\
\hline & $10-14$ & 17 & 33,3 & 33,3 & 68,6 \\
\hline & $15-19$ & 7 & 13,7 & 13,7 & 82,4 \\
\hline & $20-24$ & 6 & 11,8 & 11,8 & 94,1 \\
\hline & $25-29$ & 2 & 3,9 & 3,9 & 98,0 \\
\hline & $30-34$ & 1 & 2,0 & 2,0 & 100,0 \\
\hline & Toplam & 51 & 100,0 & 100,0 & \\
\hline
\end{tabular}

Tablo 4. Çalışmaya Katılan İlkokul Öğretmenlerinin Ĕ̆itim Seviyelerine Göre Dă̆ılımı

\begin{tabular}{llllll}
\hline \multirow{2}{*}{ Geçerli } & & Frekans & Yüzde & Geçerli Yüzde & Birikimli Yüzde \\
\cline { 2 - 6 } & Lisans & 48 & 94,1 & 94,1 & 94,1 \\
\cline { 2 - 6 } & Yüksek Lisans & 3 & 5,9 & 5,9 & 100,0 \\
\cline { 2 - 6 } & Toplam & 51 & 100,0 & 100,0 & \\
\hline
\end{tabular}

\section{Veri Toplama Aract}

“ilkokul öğretmenlerinin glokal liderlik davranışlarını sergileme düzeyleri"ni araştırmak amacıyla yürütülen bu çalışmada; Erçetin ve diğerleri (2011) tarafından geliştirilen Çok Boyutlu Glokal Liderlik Ölçeği kullanılmış; bu ölçeğin geçerlik ve güvenirlik çalışmaları yine Erçetin ve diğerleri (2011) tarafından yapılmıştır. Sözü edilen ölçek; (i) vizyon sahibi olmak, (ii) sosyal ağların yönetimi, (iii) küresel okuryazarlık, (iv) yerel okuryazarlık olmak üzere dört farklı eylem boyutunu içermekte, toplam 28 maddeden oluşmakta ve $4^{\prime}$ lü derecelendirme sistemini bünyesinde barındırmaktadır. Ölçekten alınan puan ortalamalarına karşılık gelen glokal liderlik davranışlarını gösterme düzeyleri şu şekildedir: Hiçbir zaman; 1.00 
$\leq X \leq 1.75$, nadiren; $1.76 \leq X \leq 2.50$, ara sira; $2.51 \leq X \leq 3.25$, her zaman; $3.26 \leq X$ $\leq 4.00$. Ayrıca, "ilkokul öğretmenlerinin glokal liderlik davranışlarını göstermeye yönelik demografik özelliklere (cinsiyet, yaş, kıdem, eğitim seviyesi) göre bir farklılık olup olmadığını test etmek amacıyla çalışma grubuna bir bilgi formu dağıtılmıştır.

\section{Verilerin Analizi}

Çalışmada, ilkokul öğretmenlerinin glokal liderlik davranışlarını gösterme düzeylerine yönelik tutum ölçeğinden elde edilen veriler bilgisayar ortamına aktarılarak SPSS 22 paket programı ile analiz edilmiştir. İlkokul öğretmenlerinin glokal liderlik davranışlarını gösterme düzeylerinin ortalama puanları, tutum ölçeğindeki dört bölümün maddelerinin; i(vizyon sahibi olmak), ii(sosyal ağların yönetimi), iii(küresel okuryazarlık) ve iv(yerel okuryazarlık) bir bütün haline getirilmesi ve frekans analizi ile hesaplanmıştır. İlkokul öğretmenlerinin glokal liderlik davranışlarını gösterme düzeylerinin araştırmanın bağımsız değişkenleri açısından farklılık gösterip göstermediği ise; iki kategoriden oluşan cinsiyet(kadın, erkek) ve eğitim seviyesi(lisans, yüksek lisans) için bağımsız örneklemler için $\mathrm{T}$ testi, ikiden fazla kategoriden oluşan yaş ( 25-29, 30-34, 35,39, 40-44, 45-49, 50-54) ve kıdem (0-4, 5-9, 10-14, 15-19, 20-24, 25-29, 30-34) için ANOVA (Tek Yönlü Varyans Analizi) yapılarak araştırılmıştır. Gruplar arasında homojenlik sağlandığı durumda Tukey Testi, gruplar arasında homojenlik sağlanamadığı durumda ise Post Hoc testlerinden olan Games-Howell testi uygulanmıştır.

\section{Kapsam ve Sinırlılıklar}

Yürütülen araştırmanın çalışma grubunu, Ankara ili Sincan Bölgesi Yenikent İlkokulu ilkokul öğretmenleri oluşturmuştur. Araştırma bulguları, çalışma grubu olarak seçilen 51 ilkokul öğretmeni ile sınırlıdır. İlgili çalışma grubuna Erçetin ve diğerleri (2011) tarafından tasarlanan "glokal liderlik ölçeği" sunulmuş, veriler bu ölçek ve bu ölçeğin yanı sıra yine ilgili çalışma grubuna sunulan "bilgi formu" eşliğinde toplanmıştır. 


\section{Bulgular ve Yorum}

İlkokul öğretmenlerinin glokal liderlik davranışlarını gösterme düzeylerine yönelik sonuçlar Tablo 5'te sunulmuştur.

Tablo 5. İlkokul Öğretmenlerinin Glokal Liderlik Davranışların Gösterme Düzeyleri

\begin{tabular}{|c|c|c|c|c|c|}
\hline & & Vizyonerlik & $\begin{array}{l}\text { Sosyal } \\
\text { Ağların Yönetimi }\end{array}$ & $\begin{array}{l}\text { Küresel } \\
\text { Okuryazarlık }\end{array}$ & $\begin{array}{l}\text { Yerel Okur- } \\
\text { yazarlık }\end{array}$ \\
\hline \multirow[t]{2}{*}{$\mathrm{N}$} & Geçerli & 51 & 51 & 51 & 51 \\
\hline & Kayıр & 0 & 0 & 0 & 0 \\
\hline \multicolumn{2}{|c|}{ Ortalama } & 2,8459 & 2,6639 & 2,6443 & 2,9776 \\
\hline \multicolumn{2}{|c|}{ Toplam } & 145,14 & 135,86 & 134,86 & 151,86 \\
\hline
\end{tabular}

Tablo 5’ e göre ilkokul öğretmenlerinin glokal liderlik davranışlarını gösterme düzeyleri "ara sıra" dır. Başka bir ifade ile ilkokul öğretmenleri, glokal liderlik davranışlarına yönelik eylemleri ara sıra sergilemektedir. Bunun altında kuşkusuz ki birçok sebep yatıyor olabilir. Söz konusu sebepler, bir başka araştırma kapsamında ortaya konabilir.

Öğretmenin eğitimsel amaçları gerçekleştirirken kendi dünyasına sık1şıp kalmaması büyük bir önem arz etmektedir. Erçetin' e (2000) göre vizyon, şimdiyi geleceğe yönelik yorumlama kabiliyetidir. Öğretmenlerin vizyonerlik davranışlarını ara sıra sergiliyor oluşu, öğrencilerde de benzer bir durumun ortaya çıkmasına neden olabilir. Böyle bir durum öğrencilerin küresel düzene uyumunu güçleştirerek olaylara bütüncül bir açıdan bakmalarını engelleyebilir.

Liderler, belirli amaçlara ulaşabilme, olayları yorumlayabilme gibi konularda izleyenlerini güdüleyerek etkileme gücüne sahiptirler. Sosyal ağlar, liderlerin bu güçlerini en etkili bir şekilde kullanabilecekleri yerler arasındadır. Lider vasfına sahip bir öğretmenden de sosyal ağlar aracılı̆̆ı ile kendini dünyaya açması ve güncel gelişmeleri yakından takip ederek kendini geliştirmesi beklenmektedir. Ancak araştırma sonuçlarına göre öğretmenler sosyal ağların yönetimine ilişkin glokal liderlik davranışlarını ara sıra sergilemektedir. Bu bağlamda öğretmenlerin sosyal ağlar aracılığg ile mesleki gelişimlerinin ve liderlik becerilerinin geliştirilmesine yönelik uygulamalara ihtiyaç duyulduğu görülmektedir. 
Erçetin ve diğerlerine (2017) göre glokal liderlik üç boyuttan oluşmaktadır: global düşünme, yerel düşünme, aynı zamanda hem global hem yerel düşünme. Buna göre öğretmenlerin glokal liderlik davranışlarını etkili bir şekilde sergileyebilmeleri için küresel ve yerel okuryazarlık boyutlarındaki davranışları gösteriyor olmaları gerekmektedir. Ancak araştırmada küresel okuryazarlık ölçeğinin yerel okuryazarlık boyutuna ilişkin davranış puanlarının ortalaması $(\bar{x}: 2,9776)$ kısmen diğer boyutlardan yüksek olsa da bu boyuttaki davranışlar da ara sıra kategorisinde kendine yer bulmaktadır.

İlkokul öğretmenlerinin cinsiyet değişkenine göre glokal liderlik davranışlarını gösterme düzeyleri arasında anlamlı bir farklılık olup olmad1ğını belirlemek amacıyla öncellikle bir normallik testi yapılmış, verilerin eşit dağıldığı anlaşıldıktan sonra bağımsız değişkenler için T testi yapılarak farklılık olup olmadığ incelenmiştir. Tablo 6, ilkokul öğretmenlerinin glokal liderlik davranışlarını gösterme düzeylerinin cinsiyet değişkenine göre durumunu sunmaktadır.

Tablo 6. İlkokul Öğretmenlerinin Glokal Liderlik Davranışlarını Gösterme Düzeylerinin Cinsiyet Değişkenine Göre Durumu

\begin{tabular}{lllll}
\hline \multirow{2}{*}{$\begin{array}{l}\text { Vizyonerlik } \\
\text { Sosyal Ağların Yöne-Erkek }\end{array}$} & Cinsiyet & $\mathbf{N}$ & Ortalama & $\mathbf{p}^{*}$ \\
\cline { 2 - 5 } $\begin{array}{l}\text { Simi } \\
\text { timin }\end{array}$ & Kadın & 10 & 2,6714 & 0,392 \\
\hline \multirow{2}{*}{ Küresel Okuryazarlık } & Erkek & 10 & 2,8885 & \\
\cline { 2 - 5 } & Kadın & 41 & 2,6143 & 0,792 \\
\hline \multirow{2}{*}{ Yerel Okuryazarlık } & Erkek & 10 & 2,6760 & \\
\cline { 2 - 5 } & Kadın & 41 & 2,4000 & 0,180 \\
\hline
\end{tabular}

${ }^{*} \mathrm{p}<0,05$

Tablo 6' ya göre, glokal liderlik davranış boyutlarından olan vizyonerlik, sosyal ağların yönetimi, küresel okuryazarlık ve yerel okuryazarlık boyutlarının dördünde de kadınlar, erkeklerden daha yüksek puanlar almışlardır. Fakat anlamlı bir farklılık olup olmadığını anlamak için yapılan bağımsız değişkenler için T testi sonuçlarına göre, ilkokul öğretmenlerinin glokal liderlik davranışlarını gösterme düzeyleri, cinsiyet değişkenine göre anlamlı bir farklılık göstermemektedir. 
Bir diğer bağımsız değişken olan yaş değişkenine göre ilkokul öğretmenlerinin glokal liderlik davranışlarını gösterme düzeylerinin farkl1laşma durumunun sınanması öncesi homojenlik testi uygulanmış, glokal liderlik boyutlarından olan "sosyal ağların yönetimi"nde homojenlik sağlanamadığı için bu boyuta yönelik Post Hoc testlerinden olan Games Howell testi yapılmıştır. Tablo 7, yapılan Games Howell Testi'nin sonucunu göstermektedir.

Tablo 7. Sosyal Ağlarn Yönetimi Boyutunun Yaş Değişkenine Göre Games Howell Testi Sonuçlan

\begin{tabular}{|c|c|c|c|}
\hline \multirow[t]{31}{*}{ SosyalAğların Yönetimi } & & & $\mathrm{p}^{*}$ \\
\hline & \multirow[t]{5}{*}{$25-29$} & $30-34$ & 0,986 \\
\hline & & $35-39$ & 0,999 \\
\hline & & $40-44$ & 1,000 \\
\hline & & $45-49$ & 0,980 \\
\hline & & $50-54$ & 1,000 \\
\hline & \multirow[t]{5}{*}{$30-34$} & $25-29$ & 0,986 \\
\hline & & $35-39$ & 0,612 \\
\hline & & $40-44$ & 0,960 \\
\hline & & $45-49$ & 0,614 \\
\hline & & $50-54$ & 1,000 \\
\hline & \multirow[t]{5}{*}{$35-39$} & $25-29$ & 0,999 \\
\hline & & $30-34$ & 0,612 \\
\hline & & $40-44$ & 1,000 \\
\hline & & $45-49$ & 0,992 \\
\hline & & $50-54$ & 1,000 \\
\hline & \multirow[t]{5}{*}{$40-44$} & $25-29$ & 1,000 \\
\hline & & $30-34$ & 0,960 \\
\hline & & $35-39$ & 1,000 \\
\hline & & $45-49$ & 0,999 \\
\hline & & $50-54$ & 1,000 \\
\hline & \multirow[t]{5}{*}{$45-49$} & $25-29$ & 0,980 \\
\hline & & $30-34$ & 0,614 \\
\hline & & $35-39$ & 0,992 \\
\hline & & $40-44$ & 0,999 \\
\hline & & $50-54$ & 0,993 \\
\hline & \multirow[t]{5}{*}{$50-54$} & $25-29$ & 1,000 \\
\hline & & $30-34$ & 1,000 \\
\hline & & $35-39$ & 1,000 \\
\hline & & $40-44$ & 1,000 \\
\hline & & $45-49$ & 0,993 \\
\hline
\end{tabular}

Tablo 7, sosyal ağların yönetimi boyutunun, yaş değişkenine göre anlamlı bir farklılık oluşturmadığını göstermektedir. Buna göre farklı yaş 
gruplarındaki öğretmenlerin sosyal ağ yönetimlerinin benzer nitelikte olduğu sonucuna ulaşılabilir.

Diğer boyutlar olan vizyonerlik, küresel okuryazarlık ve yerel okuryazarlık boyutlarında homojenlik sağlandığı için ANOVA sonuçlarına bakılmıştır. Tablo 8, ilgili ANOVA sonuçlarını sunmaktadır.

Tablo 8. Vizyonerlik, Küresel Okuryazarlık, Yerel Okuryazarlık Boyutlarını Yaş Değişkenine Göre ANOVA Sonuçları

\begin{tabular}{|c|c|c|c|c|c|c|}
\hline & \multicolumn{2}{|c|}{ Kareler Top- } & \multicolumn{2}{|c|}{ Kare Ortala- } & \multirow[b]{2}{*}{$\mathrm{p}^{*}$} \\
\hline & & lami & $\mathrm{df}$ & mas1 & $\mathbf{F}$ & \\
\hline \multirow[t]{3}{*}{ Vizyonerlik } & Gruplar Arasi & 1,151 & 5 & 0,230 & 0,877 & 0,504 \\
\hline & Grup İçi & 11,822 & 45 & 0,263 & & \\
\hline & Toplam & 12,973 & 50 & & & \\
\hline \multirow{3}{*}{$\begin{array}{l}\text { Küresel } \\
\text { Okuryazar- } \\
\text { lık }\end{array}$} & Gruplar Arası & 0,544 & 5 & 0,109 & 0,247 & 0,939 \\
\hline & Grup İçi & 19,838 & 45 & 0,441 & & \\
\hline & Toplam & 20,383 & 50 & & & \\
\hline \multirow{3}{*}{$\begin{array}{l}\text { Yerel Okur- } \\
\text { yazarlik }\end{array}$} & -Gruplar Arası & 1,324 & 5 & 0,265 & 0,851 & 0,521 \\
\hline & Grup İçi & 13,998 & 45 & 0,311 & & \\
\hline & Toplam & 15,321 & 50 & & & \\
\hline
\end{tabular}

${ }^{*} \mathrm{p}<0,05$

Tablo 8' e göre Çok Boyutlu Glokal Liderlik Ölçeği'nin diğer boyutları olan vizyonerlik, küresel okuryazarlık ve yerel okuryazarlık boyutlarında da yaş değişkenine göre anlamlı bir farklılık bulunmamıştır. Burada belki de araştırmanın kapsamının kısıtlılığı olası bir farklılığın anlamlılığının önüne geçmektedir.

Kıdem değişkenine yönelik glokal liderlik boyutlarında bir farklılaşma olup olmadığının tespit edilebilmesi için "30-34" değer aralığında sadece bir kişi olduğu için bu kişi veri setinden çıkarılmıştır. Tablo 9, kıdem değişkenine yönelik glokal liderlik davranışlarında farklılaşma durumunu sunmaktadır. 
Tablo 9. İlkokul Öğretmenlerinin Glokal Liderlik Davranışlarının Kıdem Değişkenine Göre ANOVA Sonuçları

\begin{tabular}{|c|c|c|c|c|c|c|}
\hline & \multicolumn{2}{|c|}{ Kareler Top- } & \multicolumn{2}{|c|}{ Kare Ortala- } & \multirow[b]{2}{*}{$\mathrm{p}^{*}$} \\
\hline & & lamı & $\mathrm{df}$ & mas1 & $\mathbf{F}$ & \\
\hline \multirow[t]{3}{*}{ Vizyonerlik } & Gruplar Arası & 2,000 & 5 & 400 & 1,633 & 0,171 \\
\hline & Grup İçi & 10,776 & 44 & ,245 & & \\
\hline & Toplam & 12,776 & 49 & & & \\
\hline \multirow{3}{*}{$\begin{array}{l}\text { Sosyal Ağla } \\
\text { rın Yönetimi }\end{array}$} & -Gruplar Arası & 3,829 & 5 & ,766 & 2,036 & 0,092 \\
\hline & Grup İçi & 16,550 & 44 & ,376 & & \\
\hline & Toplam & 20,379 & 49 & & & \\
\hline \multirow{3}{*}{$\begin{array}{l}\text { Küresel } \\
\text { Okuryazar- } \\
\text { lik }\end{array}$} & Gruplar Arası & 3,027 & 5 & ,605 & 1,539 & 0,197 \\
\hline & Grup İçi & 17,308 & 44 & ,393 & & \\
\hline & Toplam & 20,335 & 49 & & & \\
\hline \multirow{3}{*}{$\begin{array}{l}\text { Yerel Okur } \\
\text { yazarlık }\end{array}$} & -Gruplar Arası & 1,485 & 5 & ,297 & ,945 & 0,462 \\
\hline & Grup İçi & 13,836 & 44 & ,314 & & \\
\hline & Toplam & 15,321 & 49 & & & \\
\hline
\end{tabular}

Tablo 9'a göre ilkokul öğretmenlerinin glokal liderlik davranışlarını gösterme düzeylerinde kıdem değişkenine göre anlamlı bir farklılık bulunmamıştır. Bu sonuçların yaş değişkeni ile yakın anlamlı farklılık oluşturma durumlarını ortaya koyması, örgüt içerisine giren öğretmenin bu örgüt içerisinde belki de kendini geliştiremediğini ya da örgütün kendisini kısıtladığını göstermektedir.

Tablo 10, ilkokul öğretmenlerinin glokal liderlik davranışlarını gösterme düzeylerinin eğitim seviyesi değişkenine ilişkin anlamlı farklılık oluşturma durumunu sunmaktadır.

Tablo 10. İlkokul Öğretmenlerinin Glokal Liderlik Davranışların Gösterme Düzeylerinin Eğitim Seviyesi Değişkenine Göre Durumu

\begin{tabular}{|c|c|c|c|c|}
\hline & Eğitim Seviyesi & $\mathbf{N}$ & Ortalama & $\mathrm{p}^{*}$ \\
\hline \multirow[t]{2}{*}{ Vizyonerlik } & Lisans & 48 & 2,8393 & 0,713 \\
\hline & Yüksek Lisans & 3 & 2,9524 & \\
\hline \multicolumn{2}{|c|}{ Sosyal Ağların Yö-Lisans } & 48 & 2,6667 & 0,904 \\
\hline netimi & Yüksek Lisans & 3 & 2,6190 & \\
\hline \multirow{2}{*}{$\begin{array}{ll}\text { Küresel } & \mathrm{O} \\
\text { zarlik } & \\
\end{array}$} & -Lisans & 48 & 2,6458 & 0,945 \\
\hline & Yüksek Lisans & 3 & 2,6190 & \\
\hline \multicolumn{2}{|c|}{ Yerel Okuryazar-Lisans } & 48 & 2,9881 & 0,593 \\
\hline lik & Yüksek Lisans & 3 & 2,8095 & \\
\hline
\end{tabular}

${ }^{*} \mathrm{p}<0,05$ 
Tablo 10'a göre sadece vizyonerlik boyutunda yüksek lisans mezunları, lisans mezunlarından daha yüksek puan almışlardır. Fakat diğer üç boyut olan sosyal ağların yönetimi, küresel okur yazarlık ve yerel okur yazarlık boyutlarında lisans mezunları yüksek lisans mezunlarından daha yüksek puan almışlardır. Bu farklılığın anlamlı olup olmadığını ölçmek amacıyla yapılan $\mathrm{T}$ testi sonuçlarına göre ise dört boyutun hiçbirinde anlamlı bir farklılık bulunmamıştır.

\section{Sonuç}

Son yüzyılda yaşanan sosyal, ekonomik ve bilimsel gelişmeler tüm örgütler kadar eğitim kurumlarını da etkilemekte ve değişime zorlamaktadır. Bu değişim sonucunda ortaya çıkan yeni eğitim anlayışında öğrencilere, ailelere ve diğer paydaşlara rehberlik edebilecek lider bir öğretmen modeline ihtiyaç duyulmaktadır (Dinçman ve Koşar, 2016). Bu modelin başarıya ulaşabilmesi için tüm paydaşlara global ve yerel düşünme imkanı sağlayacak nitelikte olması şarttır. Bütüncül bir düşünmenin kapılarını açan glokal liderlik bu açıdan önemlidir.

lkokul öğretmenlerinin glokal liderlik davranışlarını gösterme düzeylerinin saptanması amacıyla yürütülen araştırma sonucunda elde edilen bulguların; Erçetin ve diğerleri (2017) tarafından yürütülmüş olan araştırma ile benzerlikler taşıdığı görülmektedir. Ancak söz konusu araştırmada demografik değişkenlere bağlı olarak bir farklılaşmadan söz edilirken bu araştırmada bu tür bir farkılılaşma görülmemiştir. Canbolat ve diğerleri (2018) tarafından yapılan araştırma, araştırma bulguları ile paralellikler göstermiş ve öğretmenlerin glokal liderlik davranışlarının geliştirilmesine yönelik fırsatlar sunulmasının gerekliliğini vurgulamıştır. Ancak araştırma, Brooks ve Normore (2010) ve Weber (2007) tarafından yürütülmüş olan çalışmalar ile hem amaçlar hem sonuçlar bakımından farklılık göstermiştir.

Toplanan verilerin analizleri sonucu ise;

- İlkokul öğretmenlerinin glokal liderlik davranışlarını gösterme düzeyleri "ara sıra" bulunmuştur. İlkokul öğretmenleri glokal liderlik davranışlarını ara sıra sergilemektedirler.

- İlkokul öğretmenlerinin glokal liderlik davranışlarını gösterme düzeyleri, “yaş" değişkenine göre anlamlı bir farklılık oluşturmamaktadır. 
- İlkokul öğretmenlerinin glokal liderlik davranışlarını gösterme düzeyleri, "cinsiyet" değişkenine göre anlamlı bir farklılık oluşturmamaktadır.

- İlkokul öğretmenlerinin glokal liderlik davranışlarını gösterme düzeyleri, "kııdem" değişkenine göre anlamlı bir farklılık oluşturmamaktadır.

- İlkokul öğretmenlerinin glokal liderlik davranışlarını gösterme düzeyleri, eğitim seviyesi değişkenine göre anlamlı bir farklılık oluşturmamaktadır.

\section{Öneriler}

Eğitim yönetimi alanında yeni sayılabilecek ve Türkiye'de üzerinde yeterince durulmayan "glokal liderlik", çağımızın eğitim trendlerini anlama açısından oldukça önemlidir. Bu sebeple "glokal liderlik" kavramına ilişkin eğitim kurumlarında daha fazla araştırma yapılmalı, çalışma grubunu oluşturan kişi sayısı artırılmalıdır. Çalışma grubu olarak ilkokul öğretmenlerinin yanı sıra farklı eğitim kademelerinde görev yapan öğretmenler seçilebilir. "Glokal liderlik" kavramının okul yöneticileri temelinde ele alınması da alana yeni heyecanlar getirebilir. Bu bağlamda yapılacak olan araştırmaların, Türk Eğitim sisteminin küresel ve yerel ihtiyaçları karşılama düzeyinin belirlenmesi yoluyla alanyazına önemli katkılar sağlayacağı düşünülmektedir. 


\title{
EXTENDED ABSTRACT
}

\section{Display Levels of Primary School Teachers Glocal Leadership Behaviors}

\author{
Sait Akbaşlı - Şefika Şule Erçetin - Harun Yüce \\ Hacettepe University
}

Human is a constantly changing, developing socio-cultural entity. Sos-yocultural is a result of human being interacting with other people by nature. This process of interaction paves the way for the emergence of human societies called organizations. Organizations are social systems created to achieve certain goals. Social systems are individual-oriented, goal-oriented and open to the environment (Hoy and Miskel, 2010).

People who are members of social systems take responsibility within the group according to their qualifications. Some people or persons come to the forefront during this assignment. These people, called leaders, have a significant impact on group members. Leaders, followers; their beliefs and values, their way of interpreting events, their motivation to achieve certain goals, their skills and self-confidence, their goals, and mutual trust and cooperation (Bolden, Gosling, Marturano; and Dennison, 2003). Leadership theories cannot be dealt with separately from the social and political characteristics of organizations and societies (Kantos, 2011).

Leadership is of particular importance for education management. However, when it comes to education management, the types of leadership that come to mind are mostly educational leadership and instructional leadership, and these types of leadership are generally considered on the basis of managers.

The main purpose of this study is saptan 'to determine the levels of primary school teachers showing their glocal leadership behaviors' '. In addition, based on the mentioned information, the following questions were sought within the scope of the research: 1 . What are the primary school teachers' levels of showing their glocal leadership behaviors? 2. Do 
primary school teachers' levels of showing glocal leadership behaviors differ significantly according to demographic characteristics (gender, age, seniority, educational level)?

The descriptive method was used in this study in order to determine the levels of primary school teachers' showing glocal leadership behaviors and whether these levels differ according to demographic characteristics (gender, age, seniority, education level). The descriptive method provides quantitative data and statistical possibilities. According to Knupfer and McLellan (1996), the descriptive method allows observation of the situation in its nature (Erçetin et al., 2017, p.75). The research was carried out with primary school (class) teachers (51) from Yenikent Primary School in Ankara. The distribution of teachers participating in the study according to gender, age, seniority and education level is presented in a table.

In order for global leadership to be successful, it is essential that all stakeholders have the ability to think globally and locally. Glocal leadership, which opens the doors of holistic thinking, is important in this respect. The results of the research conducted to determine the level of primary school teachers' demonstration of the glocal leadership behaviors; Erçetin et al. (2017).

As a result of the analysis of the collected data; Primary school teachers' levels of showing glocal leadership behaviors "occasionally" were found. Primary school teachers occasionally exhibit their glocal leadership behavior. The level of primary school teachers' demonstration of glocal leadership behaviors does not make a significant difference according to the variable " age ". The level of primary school teachers' demonstration of glocal leadership behaviors does not make a significant difference according to " gender 'variable. The level of primary school teachers' showing their glocal leadership behaviors does not make a significant difference according to the variable 'seniority'. The level of primary school teachers' demonstration of glocal leadership behaviors does not make a significant difference according to the educational level variable. 


\section{Kaynakça / References}

Adifatoni, Y. (2016). The educational leadership in global perspective. Script Journal: Journal of Linguistic and English Teaching, 1(1), 61-71.

Begley, M. T. ve Boyd D. P., (2003). The need for a corporate global mind-set. MIT Sloan Management Review, 44(2), 25-32

Bolden, R., Gosling, J., Marturano, A. ve Dennison, P. (2003). A Review of Leadership Theory and Competency Frameworks, University of Exeter, Centre for Leadership Studies: 1-44, http://www.leadershipstudies.com/ documents/mgmt_standards.pdf, (12.4.2019).

Brooks, S.J., ve Normore, A. H. (2010). Educational leadership and globalization: literacy for a glocal persepective. Educational Policy, 24(1), 52-82. doi: $10.1177 / 0895904809354070$

Canbolat, S., Mumcu, S., Şahan, A.,Öcal, F. ve Akdoğan, N. (2016). applicability of glocal leadership to educational institutions. chaos, Complexity and Leadership, 573-580. doi: https://doi.org/10.1007/978-3-319-64554-4

Chappelet, J. L. (2009). A glocal vision for sport and sport management. European Sport Management Quarterly, 9(4), 483-485

Çınar, İ. (2009). Küreselleşme, eğitim ve gelecek. Kuramsal Eğitimbilim, 2(1), 14-30.

Dinçman, M. P. (2016). Chaos, complexity, and leadership in the context of organizational uncertainty in education and scholl administration. In Ş.Ş. Erçetin (Ed.), Chaos, complexity and leadership 2016 (247-277). Cham: Springer.

Dinçman, M. P. ve Koşar, D. (2016). Analysis of scientific papers on organizational uncertainty in education and school administration (19902016). In Ş.Ş. Erçetin (Ed.), Chaos, complexity and leadership 2016 (407441). Cham: Springer.

Erçetin, Ş. Ş. (2000). Lider sarmalında vizyon. Ankara: Nobel YayınDağııım.

Erçetin, Ş. Ş., Potas, N., Açıkalın, Ş.N., Yılmaz, M., Kısa, N. ve Güngör, H.(2017). Glocal leadership behaviours of managers working in private institutions. Polish Journal Of Management Studies, 16(2), 74-87. doi:10.17512/pjms.2017.16.2.07

Hoy, W. K. ve Miskel, C. G. (2010). Eğitim yönetimi-teori, araştırma ve uygulama. (Çev. Ed. Selahattin Turan). Ankara: Nobel yayınları.

Kalay, I., (2016). Küresel köy'ün küyerel bir reklence pratiği olarak web dizisi: Proje 13 örneği. Global Media Journal TR Edition, 7(13), 151-168. 
Karabă̆, S. (2006). Mekânın siyasallaşması. Ankara: Gazi Kitabevi.

Knupfer, N. N. ve McLellan H., (1996). Descriptive research methodologies. [In] D. H. Jonassen (Ed.). Handbook of research for educational communications and technology. New York: Macmillan.

Rupšienė, L., ve Skarbalienė, A. (2010). The characteristics of teacher leadership. Bridges / Tiltai, 53(4), 67-76.

Weber, E. (2007). Globalization, “Glocal” development, and teachers'work: A research agenda. Review of Educational Research, 77(3), 279-309. doi: 10.3102/003465430303946

\section{Kaynakça Bilgisi / Citation Information}

Akbaşlı, S., Erçetin, Ş. Ş., ve Yüce, H. (2019). İlkokul öğretmenlerinin glokal liderlik davranışlarını gösterme düzeyleri. OPUS-Uluslararası Toplum Araştırmaları Dergisi, 14(20), 54-74. DOI: 10.26466/ opus.585869 